\title{
Rethinking Slums: An Approach for Slums Development towards Sustainability
}

\author{
Ghada Mohammad Elrayies ${ }^{1}$ \\ ${ }^{1}$ Faculty of Engineering, Port Said University, Port Said, Egypt \\ Correspondence: Ghada Mohammad Elrayies, Faculty of Engineering, Port Said University, Port Said 42526, \\ Egypt. Tel: 2-066-344-6100. E-mails: ghadaelrayies@eng.psu.edu.eg; ghadaelrayies@ymail.com
}

Received: October 8, 2016 Accepted: November 10, 2016 Online Published: November 30, 2016

doi:10.5539/jsd.v9n6p225 URL: http://dx.doi.org/10.5539/jsd.v9n6p225

\begin{abstract}
Slums have become an unavoidable reality in many countries of the world, particularly the developing world. Although there are various slums upgrading models and approaches to address the urban poverty in developing countries, the number of slum dwellers has actually grown and the problem is expected to become worse. Other public policies have to eradicate slums and didn't take into account the resources and the potentials that slums offer. This refers to the need to change the procedures followed in the development processes. Along with the human-related problems associated with slums, slums cause serious impacts on the environment and natural resources. In this context, sustainable development is the main outlet to achieve a real boom of the developing world that consequently confirms the need to develop slums in an integrated manner. So, this paper adopts a concept of investing the positive aspects of the slums' community in conjunction with developing a thorough framework based on the three pillars of sustainability, economy, society, and environment. From this vein, the research is guided by a set of successful practices of many of developing countries through an approach grounded on the three pillars of sustainability. The objectives of this paper are; 1) shedding light on the positive human power of slum dwellers, 2) disseminating best practices on sustainable approaches, from which it can be developed and adapted to fit in the context of the urban slums of developing countries, and 3) providing a comprehensive framework for developing sustainable slums.
\end{abstract}

Keywords: slums, sustainability, sustainable slums, successful practices

\section{Introduction}

The world is experiencing the largest swell of urban growth in history. More than half of the world's population now lives in cities and towns, and by 2030 this number will increase to about 5 billion causing huge environmental, economic, and social transformations (UNFPA, 2007). Urbanization is accompanied by a number of challenges posed by the concentration of population in major cities; the environmental degradation that happened very quickly, resulting in a lack of basic needs, deterioration of water quality, air pollution, and the problems of solid waste disposal (Cronin, 2012). Among theses challenges are also the deficiencies in the provision and maintenance of housing and infrastructure. Furthermore, these involve the exposure to traffic hazards, lead, air pollution, and the amplification of heat waves of Urban Heat Island. As the reliance on fossil fuels, and the number of urban consumers and their materials needs increase, cities contribute to serious hazards on the biosphere including climate change (Agrawal, 2014). The rise in the number of urban dwellers has contributed in the slum growth. These slums are characterized by overcrowding, poor housing, low incomes, a lack of sanitation and safe water, and physical and legal insecurity (Cronin, 2012). The slums, due to the lack of the basic infrastructure, also resulting in severe impacts on the environment, damaging the natural resources and debilitating the regions where they are (Andrade, Aulicino, \& Abiko, 2011).

\section{Method}

Many of the measures taken to solve the slums' problems didn't pay attention to the resources offered by these slums, as well as many of the slums have showed challenges in dealing with it for many reasons, either the shortage of lands, the funding deficits, and/or the difficulty of infrastructure supply which lead to failure in the face of slums' intractable problems. Furthermore, many interventions that have been taken through a variety of slum upgrading actions omit the investigations of the long-term sustainability. So, accepting these informal areas and investing the positive aspects of its communities as well as adopting the sustainability approach including its 
three pillars are the target of this paper. In order to move forward for the sake of this target, first, the paper sheds light on the positive aspects of slums' communities to take advantages of their energetic features. Second, the paper is guided by a set of successful practices of many of developing countries through an approach based on the three pillars of sustainability; economy, society, and environment. Successful practices have been derived from Egypt, India, Philippines, Brazil, Nepal, Indonesia, and Kenya. Case studies were selected in order to cover all aspects of the research methodology that derived from the three pillars of sustainability. Each case study provides one aspect or more so that the total of all cases covers the methodology.

\section{Slums}

\subsection{Slums Definition}

According to UN-HABITAT, the "slum" has been defined as a region that shares various features, including overcrowding, poor quality housing structures, insecure housing statement, inadequate access to safe drinking water, sanitation and infrastructure (Purcell, 2012; TRP, 2012). Moreover, these settlements are characterized by a lack of the basic municipal services such as street lighting, sidewalks, and paved roads to reach the emergency. The generality also doesn't have easy access to hospitals, schools, and public places (Alliance, 2014). Commonly, slums are characterized by poverty, unemployment, and urban decay. Traditionally, they are seen as breeding grounds for social issues such as crime, drug addiction, and high rates of mental illness. Furthermore, they reveal high rates of disease due to malnutrition, unsanitary circumstances, and lack of basic health care (Taher \& Ibrahim, 2014).

\subsection{Slums in Figures}

According to UN-Habitat (2013), approximately a quarter of the world's urban populations live in slums. 863 million are the number of dwellers lives in slums in the developing regions of the world according to UN-Habitat estimation, which indicates that one-third of the urban population of the developing world is living in slums. According to the same source, in Africa, more than half of the population in urban areas (61.7\%) lives in slums. In Asia, 30\% of the urban population also settles in slums according to State of the World Cities Report (2012/2013), and Asia is currently home to half of the urban population of the world. While the percent of the urban population live in slums in the developing world has dropped from $39 \%$ in the year 2000 to $32 \%$ in 2010 , indicating that a number of countries are going ahead to improve the lives of the urban poor , however, a number of slum dwellers has actually grown considerably, and expected to rise in the near future (UNHABITAT, 2014).

\subsection{Causes of Slums}

The rapid urbanization accompanied by industrialization has resulted in the growth of slums. The high land prices, the shortage of land for housing out of reach of urban poor and the migration from the countryside to the cities are feeding the expansion of slums (Goswami \& Manna, 2013). Slums are also products of failed policies, mismanagement, corruption, improper regulation, dysfunctional land markets, unresponsive financial systems, and a substantial lack of political will. All of these failures increase the burden of people already deeply loaded by poverty and restrain the vast opportunity for human development that offered by urban life (WorldBank \& UNCHS(Habitat), 2001).

\subsection{The Positive Aspect of Slums}

While recognizing all the negatives those related to slum areas, the positive aspects of those slums are absent from the perspective of many who see it as a problem that should be eradicated (Mahgoub, 2014). It is important to consider the positive and vibrant and active nature of the slum's communities. These cities-within-cities are wellsprings of entrepreneurial vitality, yet their more savage physical conditions limit their residents' ability to recognize welfare enhancements from their own endeavors alone. They have the potential to produce a significant share of the local capital formation through the self-constructed housing, nevertheless, their lives are insecure by the absence of the basic public involvements that would spur and encourage private investment. Slums are still attractive urban environments for people to live and to look for jobs. In the developing world, slums are frequently the dwelling places of abundant of the work power of the city. The contribution of slum residents to the border economy is significant as they provide a number of vital products and services to the formal economy. This informal economy is producing a very large part of the economic value of the nation. Informal sector economists such as Hernando De Soto have long argued that the poor are sitting on huge amounts of a dead capital (Cronin, 2012; WorldBank \& UNCHS(Habitat), 2001).

Further, slums provide the shelter, jobs and the hope of the livelihood that is within reach of the low-income people. Many young people find there the hope of having the proper accommodation to start their family life. Moreover, most slums are located in the centers of the city and on the best views of the natural, historical and 
architectural landscapes. So, according to Mahgoub (2014), any attempt to eradicate slums is free of logic, wisdom and proper planning. Slums are distinguished with the economic and social convergence between classes, and the ability of people to communicate among themselves and thus their ability to make a difference (Mahgoub, 2014).

\section{Sustainable Development}

There is a growing global awareness of the necessity for sustainable development to handle the looming environmental problems of global warming and climate change, emissions and resources depletion caused by human activities (SDN, 2009). Upgrading processes are multi-sectorial operations that combine environmental, economic and social interventions. They match with the aim of sustainable urban development of making healthy, economically urban communities that are socially just regarding their access to better services and the adequate urban environment. Upgrading also manages resource utilization by relying on structures and existing efforts. According to Abdelhalim (2010), the sustainability of urban development is more ensured when local residents feel the ownership of their locality (Abdelhalim, 2010).

The slums, as mentioned before, cause severe impacts on the environment damaging the soil's water quality and the water springs, and debilitating the regions wherever they are (Andrade et al., 2011). Sustainable development is the main outlet to accomplish a real boom of the developing countries and the entire world, which consequently affirms the need to develop slums. So, this paper sets an interdependence model of sustainability in slums redevelopment, according to the conceptual framework of the research (see Figure 1). It considers the three pillars of sustainability and the issues related to each pillar.

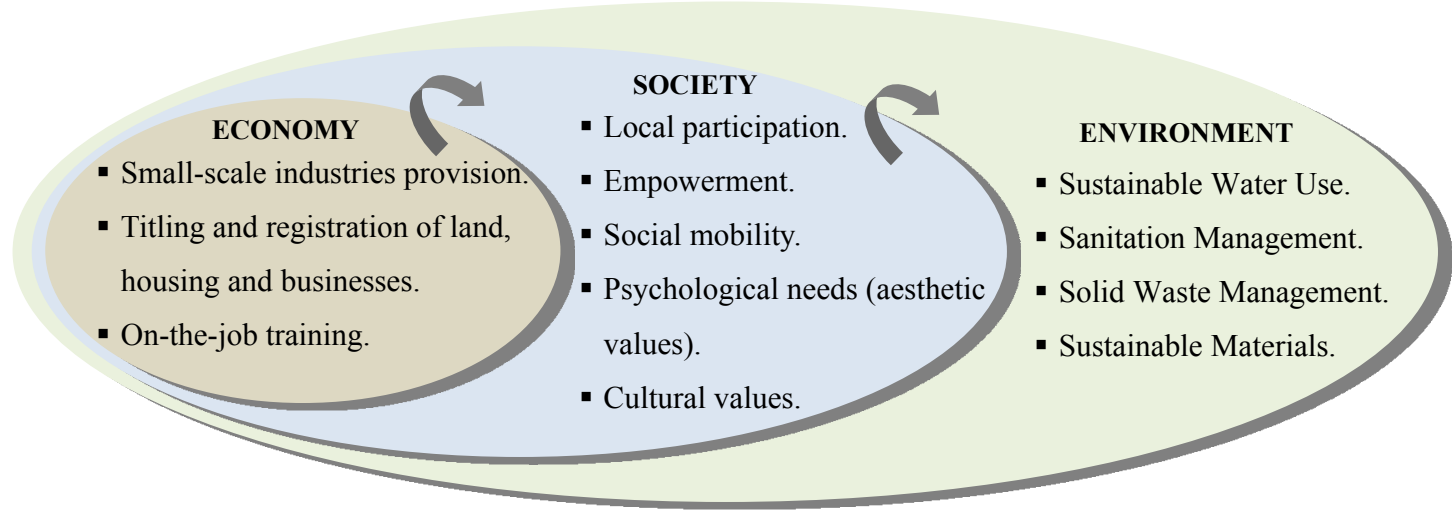

Figure 1. The interdependence model of sustainability in slums redevelopment according to the conceptual framework of the research

\subsection{Economic Aspect}

Economic development is the key to poverty eradication (DID, 2014). The slum economies play a vital role in meeting the livelihood needs of the slum dwellers in developing countries. Furthermore, they contribute considerably to the growth of urban economies in developing countries with their large proportion of the formal labour force. They contribute to the provision of urban services (waste collection), and the production of goods (such as the day-to-day products) for local markets and export (Rockefeller, 2013). It is crucial to provide the poor with the decent jobs that insure both secure income and empowerment. The social perspective on development accentuates the view that the best access to socioeconomic development, personal wellbeing, and poverty eradication is through the decent work. Unemployment lies at the heart of poverty. For the poor, labour is frequently the only asset they can use to improve their livelihood. Thus, the creation of productive employment opportunities is substantial for achieving poverty reduction and sustainable social and economic development. Productive employment opportunities will contribute essentially to achieving the goals of the agreed internationally development, notably the Millennium Development. Generally, Poverty Reduction Strategies should care about employment, social protection, and rights at work, and provide equity, security, and dignity (UN, 2005).

\subsubsection{Constraints of Informal Economic Growth}

Despite the significance of poor economies, they adversely affected by economic, political and social rooted policies in developing countries, which restrict the economic opportunities for slum dwellers. Social isolation, 
lack of law power, and the unsafe access to public and private property constitute these constraints (Rockefeller, 2013). The informal economy is lacking the productivity growth due to substantial unskilled labour. So, it is necessary to supply poor people with the required skills and assets that will enable them to take full advantage of any expansion in employment potential (UN, 2005). Furthermore, the illegal status of the informal economy makes it underused and underestimated. Titling and registration of land, housing and businesses could raise the value of the dead capital of informal houses. They could be also increase the investment potential for owners, hence, contribute to alleviate poverty. According to Abdelhalim (2010), it is possible to allocate a part of the taxes and revenues collected from the formal houses and businesses as financing sources for the development measures if they are kept locally (Abdelhalim, 2010).

\subsubsection{Micro Industries and Small-Scale Enterprises}

The opportunity for the growth of the small-scale enterprises in the informal economy is great, because of ; 1) the ease of the start-up, 2) the availability of jobs that suit unskilled labour, 3) the relatively low cost of investment compared to other medium and large industries; 4) the possibility of the involvement of the whole family; and 5) the reliability of much of these industries on the local raw materials and the reusing of damaged materials or remnants of raw materials and by-products of certain crops and industries, that is also locating in the heart of environmental sustainability (Allam, Osman, \& Mahdi, 1997; UN, 2005).

The informal urban economy promises to be the main source of new job creation as occurred in Latin America and Africa during 1990s. This informal economy represented in micro enterprises, own-account workers, and domestic services. United Nations (2005), stated that employment strategies should include promoting micro projects, developing small and medium-sized enterprises, supporting microfinance, and encouraging training and skill formation. Among the necessary elements for creating such jobs are investing in labour-intensive industries, particularly agriculture, and encouraging the higher productivity occupations and sectors (UN, 2005).

Allam et al. (1997), suggested the following procedures to promote the small industries in slums; 1) conduct surveys and detailed studies on the available materials in those communities and determine the quality of the industry to suit each region; 2) allocating organizations to do financial and feasibility studies to figure priorities; 3 ) raising awareness of the importance of the role of small-scale industries in development through voluntary participation, media, local administration and community development associations; 4) setting up funds to support small-scale industries in slums (from donations and foreign organizations); 5) developing a plan for marketing by trade fairs, both in local and foreign markets ; and 6) improving skills of local dwellers through training programs (Allam et al., 1997). a practice shows the unique ability of the poor to draw their economic lives and earn livelihoods will be presented in this section; the Garbage City in Cairo, Egypt.

\subsubsection{Case Study: the Garbage City of Cairo}

A community-based economic sustainable practice will be presented here; the Garbage City of Cairo (the Zabaleen). The Zabaleen experience reveals the role and the strength of the community knowledge as a source for financial and community-based assets (W. S. Fahmi \& Sutton, 2006). The Garbage city locates among seven scattered settlements in Manshiet Nasser slum in Cairo (Nazmy, 1993). The "Zabbaleen", the dwellers of the Garbage City, refers to the garbage collectors of Cairo who handle about $50 \%$ of the city's waste and recycle nearly $85 \%$ of it (Mourad, 2012). By comparison, most Western garbage collecting companies can only recycle about 20 to $25 \%$ of the waste that they collect (GarbageDreams, 2010). Wael Fahmi and Keith Sutton (2010), stated that the Zabaleen have created one of the world's most efficient resource-recovery and waste-recycling systems (W. Fahmi \& Sutton, 2010).

The Zabaleen collect the garbage on donkey-pulled carts. The garbage is dumped directly into the Zabaleen's homes. Female and younger members of the family classified the garbage into up to 16 different types of waste. They use the organic waste for feeding pigs and for the production of higher grade compost. They buy pig meat to big tourist hotels, and the organic waste recovery system contributed to environmental benefits. Moreover, the residents sell the classified secondary materials such as paper, tin, rags, glass, plastic materials to middlemen. The Zabaleen's recycling system prevents the land from being used as unsanitary landfills as well as protecting the air from the uncontrolled burning of garbage. Despite the harsh environmental conditions within the settlement, the Zabaleen have used wastes to secure their livelihoods and to create financial assets in order to improve their infrastructure, education, and other services (W. S. Fahmi \& Sutton, 2006).

A unique initiative, the Recycling School of the Garbage City, had been established in order to improve the community's livelihood conditions through non - formal education. In December 2001, the Community and Inistitutional Development (CID) designed and launched the Recycling School for boys in Mokattam with the support of the UNESCO under the sponsorship of the AGCCD (Association of Garbage Collectors for 
Community Development). Later, the project became under the sponsorship of the SYAES (spirit of youth association for environmental services), which was established by youths in Mokattam neighborhood in 2004. It is established as a way to help the informal waste collectors to get rid of long-term poverty (Baraka, 2012). The school follows a unique "learn-and-earn" program in tandem with the non-formal education model. The boys are collecting empty plastic bottles, to be processed into the Plastic Crusher Machine that crushes shampoo containers (that were supposed to be refilled with fake liquid) into small particles ready for pelletizing, to be used later in plastic recycled products (Mourad, 2012). The school re-sells the granulated plastic to small and medium-sized recycling companies in the neighborhood. The income created from the sale of the granulated plastic covers the salaries of the 16 teaching staff, and makes the project economically sustainable. The multinational shampoo company pays to the youth around 35 piasters for every collected and granulated bottle. The income created by the 40 students by the collecting and granulation of approximately 500,000 bottles per year contributes to enhance the livelihoods of the families of the garbage collectors (Howeidy et al., 2009).

The Zabaleen have created a recycling model that costs the state nothing. They have recycled so much waste and created job opportunities to a large number of the poorest of Cairo (GarbageDreams, 2010). The environmental and economic efficiency of the Zabaleen waste collection and recycling system have met recognition and approval of the major countries of the world at the Rio Earth Summit in 1992. The Mega-Cities Project sought to encourage the Zabaleen system of resource-recovery and waste-recycling as a constructive model to other developing world cities (W. S. Fahmi \& Sutton, 2006).

Though, after that, the Zabaleen's live has been worsened as a result of three decisions of the Cairo municipal government. The informal community of garbage collectors was challenged by a serious threat with the advent of multinational waste management firms contracted by the Egyptian government to develop a centralized waste collection system (Baraka, 2012). Contractually, the foreign firms obligated to recycle only $20 \%$ of the garbage they collect, leaving the rest to be molded in the landfills. Moreover, the foreign workers displaced the Zabaleen, and thus dispersing their way of livelihood (GarbageDreams, 2010).

What made the situation even worse are the actions taken by the government to move the Zabaleen's activities outside the city, claiming that this will turn the neighborhoods into cleaner living environments, while still allowing occurring for waste sorting, recovering, trading, and recycling. But these relocation plans will increase the mobility distance and the cost of services delivered to the residential and commercial places, thus creating further risks to the sustainability of the Zabaleen's livelihood (W. S. Fahmi \& Sutton, 2006).

Another threat was the preventive measure against the threat of the swine flu outbreak, where the Cairo government ordered the culling of all pigs in Manshiet Nasser. Pigs have always been an important factor in the lives of the Zabbaleen, as they cleanse the garbage from all organic waste, and their meat sold to hotels and restaurants catering to non-Muslims tourists (Obscura). These measures have threatened the sustainability of the garbage collectors communities by removing their access to the prime economic assets, the garbage waste. The Zabaleen experience is a comprehensive practice that includes the three pillars of sustainability; environment, economic, and community (W. S. Fahmi \& Sutton, 2006).

\subsection{Social Sustainability}

Social sustainability means the endeavor of achieving the equal participation of different groups in all stages in the development processes. It is significance to avoid excluding low-income people. This is especially critical in developing countries where low-income people are often excluded in the formal planning processes (UNHABITAT, 2012a). Social sustainability can be achieved by clarifying four coherent and compatible interventions, namely; social inclusion, participation, empowerment, and community mobilization. Through careful online search, it was found that these interventions may be different in terms but are closely related and consistent in content and in target. It could be said that: social inclusion entails the participation of the residents in their upgrading processes. The participation of the residents in the informal areas upgrading processes requires the empowerment of the local citizens. The empowerment process leads to community mobilization where local people become accountable and reliable even after the end of the upgrading process.

Social sustainability could be achieved through upgrading processes, where they contribute to give the slums' residents the feeling of being a part of the society and make them feel their value as citizens that deserve equal access to livelihood needs such as food, clean water, clothing, shelter, healthcare, education, transportation and other public services. Social inclusion means meeting the basic needs of the dwellers of the informal areas so that people can live in dignity. It promotes equal opportunity for all groups within the society and rejects the stigma linked to informal areas and their residents (Abdelhalim, 2010).

The link between social sustainability and participation is done through the involvement of inhabitants in the 
urban design of their communities to guarantee meeting their needs and desires. Effective and sustainable social development entail considering residents of informal areas as partners in the development process not mere as beneficiaries. The feelings of marginalization, neglect, and lack of trust determine the dwellers' relationship towards the government. Residents' participation in the upgrading processes involves all the stages of the development processes, including planning, implementing, monitoring, and improving facilities and services. The involvement of citizens and other local stakeholders ensures that the upgrading measures are constantly moving towards their priority needs, taking into account local conditions and take advantage of local resources. Participation of all local stakeholders needs an honest broker that holds people's trust. If the local government will be this facilitator, proper legislation, policies and methods of participation have to be adopted. Participation in urban upgrading, however, needs support and political will from the local government. The participation mechanisms require actions by decision-makers and stakeholders on three levels; the local level (communities and districts), the regional level (governorates), the national level (ministries) (Abdelhalim, 2010; Oosterlynck, Broeck, Albrechts, Moulaert, \& Verhetsel, 2011) and the international level.

As highlighted before, participation requires the empowerment of the local citizens. This ensures developments to be directed towards the local's needs, and thus be more efficient and cost-effective. Empowerment gives the local people the right to make decisions about upgrading their neighborhood. This comes by increasing the capacity and skills of local individuals and institutions to translate their choices into actions and to push and turn the selective actions for improving their living conditions. Empowerment is essential to forming qualified partnerships, where local communities are considered on equal level with other official stakeholders. Empowerment should be boosted with fairness and equity, and the least-represented groups should be provided with an equal opportunity to participate in decision-making (Reviews \& Cram101Textbook, 2012).

Engaging community's individuals, groups, and organizations in their development processes ensures identifying their needs, priorities, resources, and the proper solutions in such ways that guarantee and promote accountability, good governance, and accountability. This engagement ensures the achievement of community mobilization (Corps, 2006). Mobilization begins a dialogue among community members to determine who, what, and how issues are handled, and also to provide a pathway for everyone to participate in decisions that influence their lives (Reviews \& Cram101Textbook, 2012). To facilitate community mobilization, more dynamic and low cost opportunities for information exchange are required. Amongst these tools; radio, media, mobile technologies (SMSs), and the Internet (Websites, Social networking, Blogging platforms, YouTube and Skype) (Corps, 2006).

Next to the above-mentioned, instilling the sense of belonging, civic pride, enjoyment and integration in local people also come through the fulfillment of their psychological needs including aesthetic values (Lanrewaju, 2012; Oosterlynck et al., 2011). Figure [2] illustrates some initiatives targeting developing aesthetic values in informal settlements in Kenya, Egypt and Brazil. Attempts represented here are made through local people such as in Kenyans youth initiative, by NGOs such as in Egypt, and by artists and local help such as in Brazil.

a)

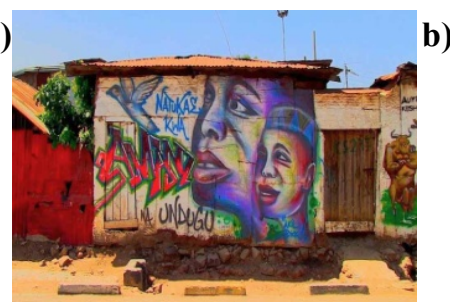

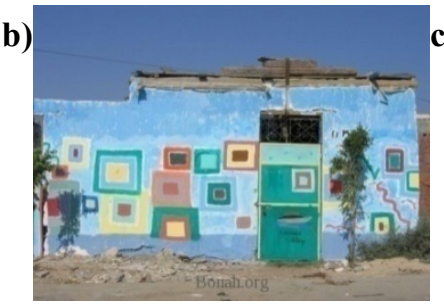

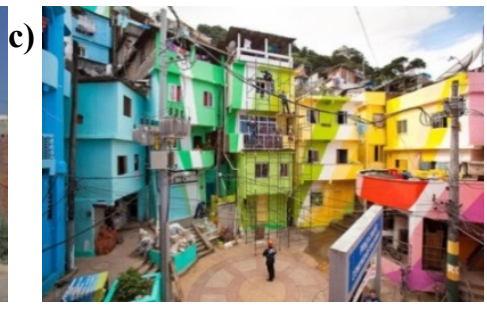

Figure 2. Instilling the aesthetic value is one of the targets of social sustainability; a) Mural art by local youth in Korogocho slum, Nairobi Kenya (AfricanSlumJournal, 2015); b) El Max, Alexandria, Egypt, the initiative by Gudran NGO (Gudran); and c) Favelas of Rio de Janeiro, Brazil (Johansson, 2010)

Cultural preservation is an important aspect that shouldn't be overlooked in the stream of social sustainability. Poor urban areas may also be sites of rich cultural diversity embedded in different cultural, social and political identities. And the role of heritage and cultural identity in these settlements should be highlighted as the slum dwellers may have a sense of place and therefore, should have rights to a cultural heritage. This sense of place contributes to social inclusion and social solidarity, and subsequently supports sustainable regeneration. Moreover, the integration of the cultural aspects can give new perspectives on slum development and environmental issues. This achievement can be translated into a cultural dimension of sustainability, particularly, when boosted by considering lifestyles and behaviours of occupants and communities that subsequently 
supporting the dignity of communal life (Johnsrud, 2009; UNHabitat, 2012d). The following section reviews an excellent example of local self-management and citizen-government collaboration from Egypt; Mīt 'Uqba paving initiative.

\subsubsection{Case Study: Mīt 'Uqba, Egypt}

Mìt 'Uqba is a popular neighborhood suffers from a lack of services, especially sanitation, which often sink the streets, causing many damages and creating daily traffic problems for both pedestrians and vehicles. Like most slum dwellers, Mìt 'Uqba's population lacks the means to meet their local needs. The most important element of the initiative was the awareness grassroots mobilization done by the youth and the residents of Mit 'Uqba that led to maximizing the very limited public resources of the Aguza district. This was attained by channeling these resources into priorities set by the neighborhood residents themselves. After consulting with several engineers, the Popular Committee suggested the use of cement interlocking paving blocks instead of asphalt, for their lower-cost, and their potential to be dismantled and reinstalled compared with asphalt. This choice allows facilitating the maintenance and preserving the street life as long as possible. Many of Mìt 'Uqba residents participated in the initiative, in cleaning, collecting garbage, paving and planting trees along the repaved streets (see figure 3). The positive outcome has encouraged the members' desire to keep it clean. Moreover, the success of the Popular Committee has encouraged them to propose new ideas to develop the neighborhood and solve future problems. Local community participation here fulfills sustainability in its three pillars; socially, by engaging all local community members in the improvement process at its all levels; economically, by the sustainable choice of cement interlocking; and environmentally; by conserving the materials and the streets as long as possible (TADAMUN, 2013).
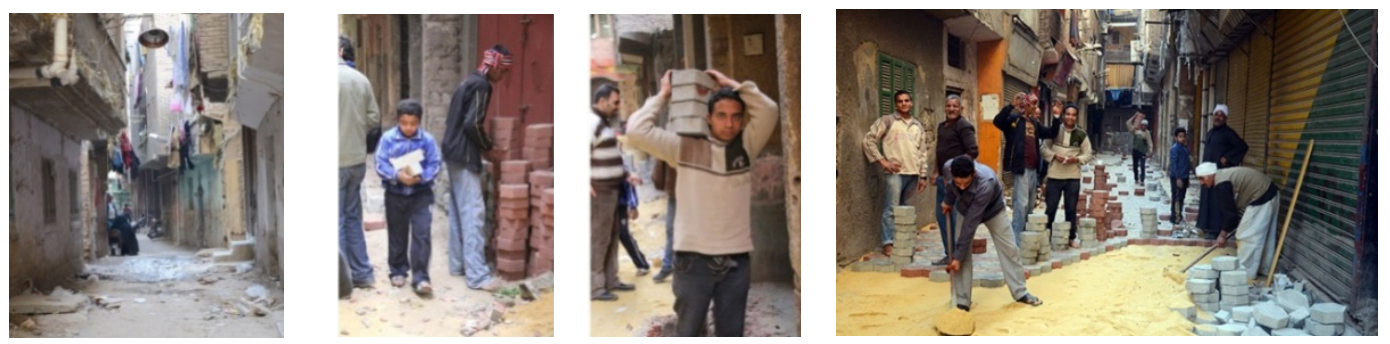

Figure 3. A social sustainability lesson from Egypt: local participatory in Mìt `Uqba, Giza, Cairo, Egypt

(TADAMUN, 2013)

\subsection{Environmental Sustainability}

Environmental sustainability is a multifaceted issue, it addresses creating a balance between varieties of matters. These matters enclose energy-related considerations as energy reservation in construction, manufacturing and transporting of materials, the use of renewable energies, and the design and planning for energy efficiency.

As well as identifying available local materials, reusing and recycling, avoiding pollutants and toxins, rainwater harvesting, and the safe disposal of waste (UNHABITAT, 2012a).

It is agreed that poverty, represented in the lack of access to clean water, inadequate sanitation and poor waste disposal, indoor air pollution, and overpopulation, are the main determinants of the environmental health status for the slum dwellers. Improving the health and living conditions of millions of slum dwellers worldwide is a basic requirement for the current Millennium Development Goals to reduce poverty (Lukeman, Bako, Omole, Nwokoro, \& Alakinde, 2014). In this section; sustainable use of water, sanitation, solid wastes, and local materials will be investigated.

\subsubsection{Sustainable Water Use}

Human health relies on the quality of the surrounding environment including water management (UNESCO, 2014). In many poor communities, the access to in-home piped water isn't available (Bell, Kumar, Lundgren, \& Schrempp, 2011). Poor women and girls have to bring water from distant sources and queue for water, which is a time-consuming responsibility. Without safe water to drink and to stay clean, children are at risk. In such circumstances, parents are often helpless to give convenient care to their children and are themselves susceptible to diseases (UNESCO, 2014). They don't have money for the expensive alternatives and are compelled to share overcrowded public taps and store water randomly (Bell et al., 2011). Integrated water resources management (IWRM) satisfies the users' water needs for economic and social activities and consequently, ensures 
environmental sustainability. Safe disposal and adequate treatment of wastewater conserves ecosystem, and contributes to relieve pressure on the scarcity of fresh water resources and consequently, reducing our vulnerability to climate change (UNESCO, 2014). Herein, when we talk about the sustainable water use, we are talking about the mechanism of supplying slums with drinking water, in addition to rainwater harvesting.

\subsubsection{Case Study: Mumbai, India}

In Mumbai, India, inadequate water supply is a daily struggle for 10 million slum dwellers. The Slum Water Program (SWP), the community-driven, decentralized comprehensive water program of ReachOut Water Solutions (ROWS) has been developed to answer the water needs of Mumbai's slum residents by expanding the decentralized water infrastructure services. The sustainable effective water solution addresses basic four primary elements; quantity, quality, access, and management (see Table 1 and Figure 4). This approach directly addresses potential water needs of customers, creating a product that saves the user's time, improves the user's health, and provides him with the greatest amount of water, all while saving the money the user is currently paying for water According to the project's operators, the SWP is characterized by rapid implementation within the current decentralization service delivery system in Mumbai, the adaptability to future changes of slum settlements, the provision of the adequate supply of safe and accessible water at an affordable price, and being a model of self-sustainability and cost-recovery system in slums throughout the world. The SWP is a simple solution that requires involvement of multiple groups to solve the complex problem; the people in the community, the CBO (community based Organizations), ROWS (Reach Out Water Solutions), the sponsor, the BMC (Brihanmumbai Municipal Corporation), the Contractor and Politicians (Bell et al., 2011) (see Figure 5).

Table 1. The four issues for the sustainable solution of water developed in Mumbai, India- case study of the SWP

\begin{tabular}{|c|c|c|c|c|}
\hline Issue & 1. Quantity Of Water & 2. Quality Of Water & 3. Access & 4. Management \\
\hline The Need & $\begin{array}{l}\text { The need for increasing } \\
\text { quantity of water }\end{array}$ & $\begin{array}{l}\text { The need for improving } \\
\text { quality of water }\end{array}$ & $\begin{array}{l}\text { The need to improve } \\
\text { access to water }\end{array}$ & \\
\hline $\begin{array}{l}\text { The } \\
\text { Current } \\
\text { State }\end{array}$ & $\begin{array}{l}\text { The water supply } \\
\text { provided by the } \\
\text { municipality in Mumbai, } \\
\text { at } 30 \text { liters per capita per } \\
\text { day, is not adequate to } \\
\text { meet daily needs. }\end{array}$ & $\begin{array}{l}13 \% \text { of the total } \\
\text { municipal piped water } \\
\text { reaching Mumbai slums } \\
\text { is contaminated with } \\
\text { illness-causing bacteria. } \\
\text { This leads to over } 6 \\
\text { million instances of } \\
\text { waterborne illness each } \\
\text { year, and nearly } 6,000 \\
\text { deaths/year, and hence, } \\
\text { losing productive hours. }\end{array}$ & $\begin{array}{l}\text { The water reaches the } \\
\text { slums isn't easily } \\
\text { accessible to the slum } \\
\text { dwellers. The } \\
\text { municipality doesn't have } \\
\text { resources to pipe water } \\
\text { to the slum homes, and } \\
\text { bottled pay-per-use water } \\
\text { is mostly too expensive } \\
\text { for the average slum } \\
\text { resident ( } \$ 0.25 / \text { liter). }\end{array}$ & $\begin{array}{l}\text { The BMC } \\
\text { (Brihanmumbai } \\
\text { Municipal Corporation) } \\
\text { is simply not capable of } \\
\text { providing water services } \\
\text { to all the residents of } \\
\text { Mumbai, especially to } \\
\text { the slum residents. }\end{array}$ \\
\hline $\begin{array}{l}\text { The } \\
\text { Solution }\end{array}$ & $\begin{array}{l}\text { The SWP planned to } \\
\text { provide } 20 \text { liters of } \\
\text { treated municipal water } \\
\text { and } 30 \text { liters of treated } \\
\text { groundwater to SWP } \\
\text { members, as well as a } 10 \\
\text { liter pay-per-use potable } \\
\text { option for non-SWP } \\
\text { members. }\end{array}$ & $\begin{array}{l}\text { The SWP intends to } \\
\text { remove } 99.99 \% \text { of the } \\
\text { bacterial contamination } \\
\text { using a small ultraviolet } \\
\text { (UV) treatment device } \\
\text { that is already in use } \\
\text { across rural India. }\end{array}$ & $\begin{array}{l}\text { The SWP planned to } \\
\text { have two customer types, } \\
\text { SWP members, and } \\
\text { pay-per-use customers. } \\
\text { SWP delivers sealed and } \\
\text { compressible plastic } \\
\text { containers to both types } \\
\text { of customers by allowing } \\
\text { them to either collect the } \\
\text { water from the SWP or to } \\
\text { have water delivered } \\
\text { directly to their home for } \\
\text { a small fee. }\end{array}$ & $\begin{array}{l}\text { By partnering with the } \\
\text { BMC and the established } \\
\text { CBOs, The SWP planned } \\
\text { to provide a water } \\
\text { services solution } \\
\text { managed by the } \\
\text { community utilizing an } \\
\text { existing customer base } \\
\text { that already pays for } \\
\text { improved infrastructure } \\
\text { services. }\end{array}$ \\
\hline
\end{tabular}

Source: The author based on (Bell et al., 2011)

\subsubsection{Rainwater Harvesting in Slums}

Rainwater harvesting is the collection and filtering of rainwater for reuse. This process could be executed by the 
households themselves. Slum dwellers, in particular, can benefit from this technique. Rainwater can provide a significant and additional source of free potable water, for toilet flushing and for irrigation, but it should be purified before being used for drinking. The impediments face rainwater harvesting are the safe storage of the water, particularly after the monsoons, and the lack of rain during most of the year (ASLA, 2010; Bell et al., 2011; SDN, 2009).

a)

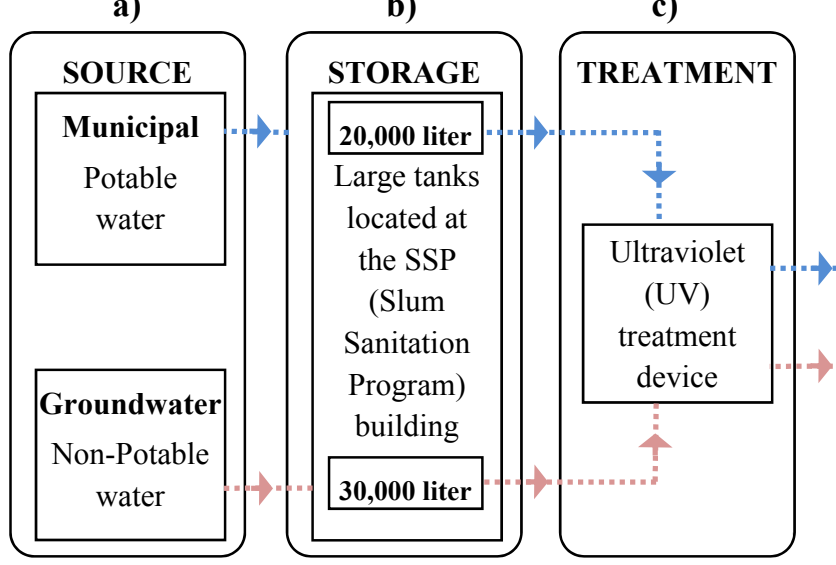

d)

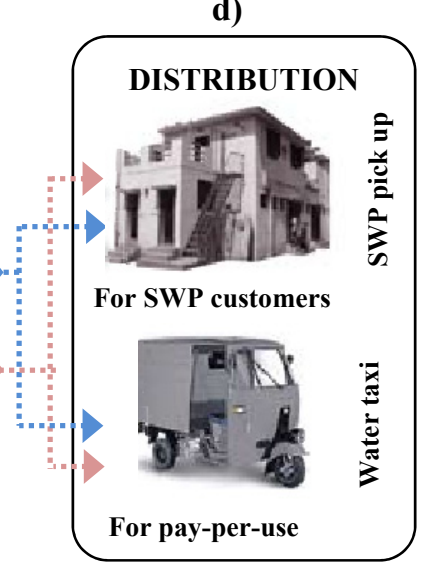

Figure 4. A scheme showing SWP for sustainable water use in Mumbai, India;

a) The SWP includes two water supplies; b) storage for 50,000 L of water; c) UV Treatment; and d) two methods of distribution (water taxi for pay-per-use customers and SWP pick up for SWP customers) (Bell et al., 2011)

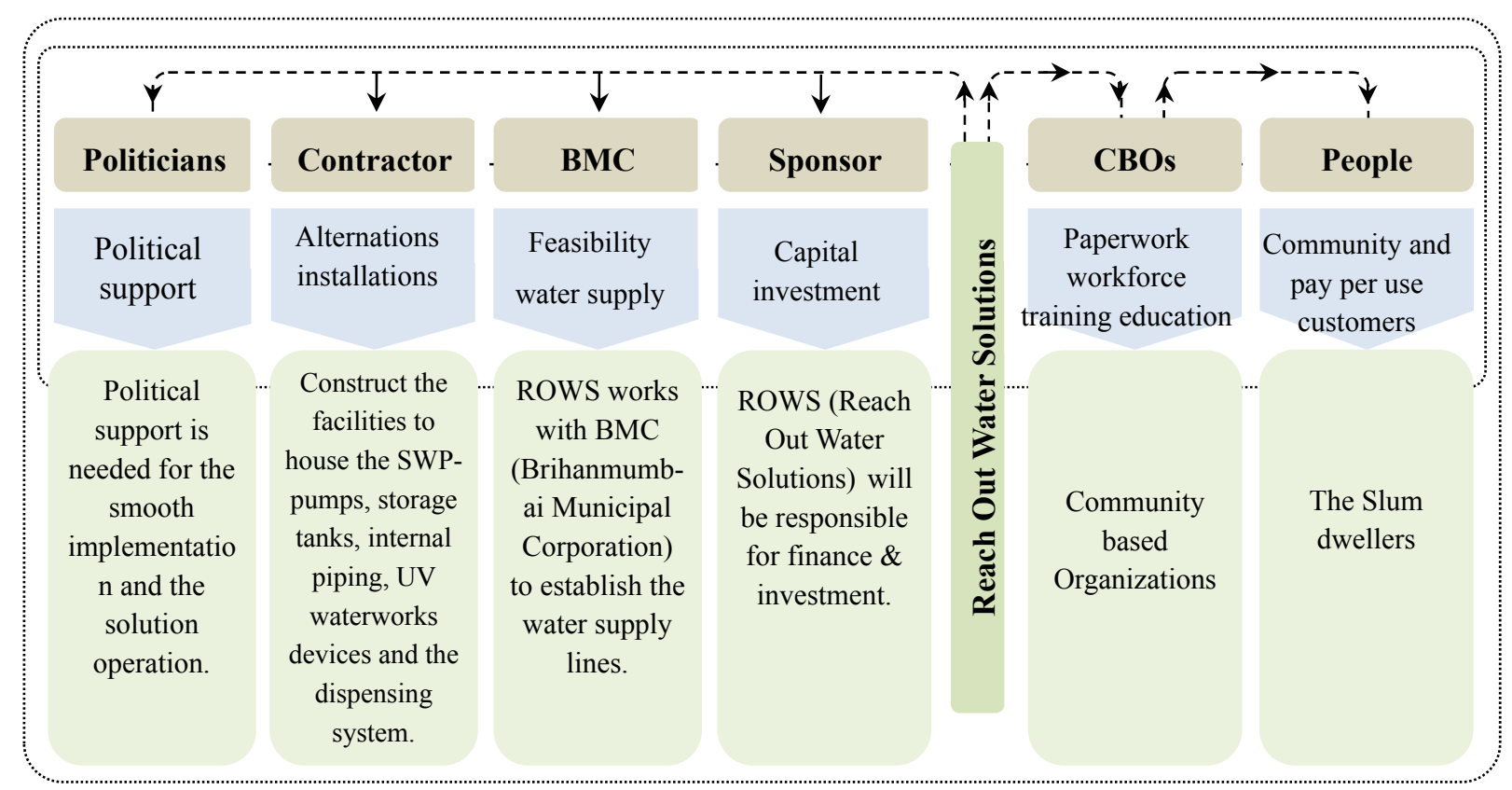

Figure 5. Participants structure in the SWP. Source: drawing by the author based on (Bell et al., 2011)

a) Case Study: the Productive End Walls, Manila, Philippines

The Productive End Walls project is a student project honor awarded (2010) from American Society of Landscape Architects. The project is an integrated solution for poor neighborhoods to achieve sustainable water use, economic and social sustainability. The project aims to develop the economic situation of the poor by taking advantage of the underused end walls of their low-cost housing relying on rainwater harvesting (see figure 6-a, 6-b). The participation of the residents is at the heart of the design. The anticipated benefits are generating food for local dwellers and improving their livelihood standards with a low cost intervention. The idea can be applied in slums wherever availability of rain (ASLA, 2010).

b) Case Study: the Sustainable Tower, Florianópolis, Brazil 
The solar water heating and rainwater tower in Brazil is the bronze awarded project of the second Holcim competition for Sustainable Construction in Latin America. The project was developed as a sustainable, economic, and innovative solution to the widespread lack of public infrastructure in poor urban areas. The Tower is an integrated unit that provides rainwater harvesting for non-potable uses, potable water storage and solar water heating where it can be installed in either new or existing residences (see figure 6-c, 6-d). This system is suitable for all climates, whether with abundant rainfall or little rainfall (Bustler, 2008; HolcimAwards, 2009).
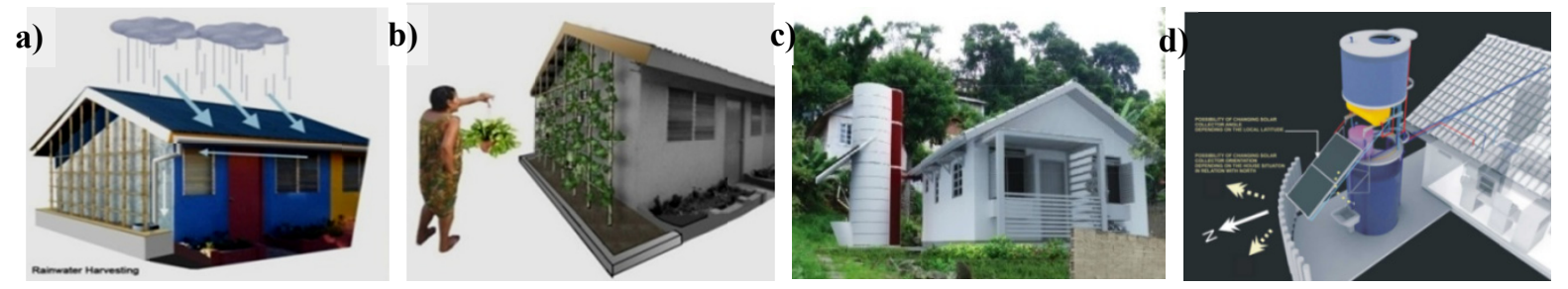

Figure 6. Rainwater harvesting applications; a),b); the Productive End Walls (ASLA, 2010); c),d); the Sustainable Tower (HolcimAwards, 2009)

\subsubsection{The Sustainable Management of Solid Waste}

The problem of Solid Waste Management (SWM) is associated with all problems related to population overcrowding, whether it is the uninterrupted migration from rural to urban areas, non-codified urbanization, the uncontrolled sprawl of squatter settlement in city centers and on the edges, or traffic congestion on all access points in cities. Therefore, governments lose the financial and physical control over solid waste disposal especially with regard to urban poor's. Furthermore, we find that the poor are forced to deal with it themselves, which lead to serious consequences, whether on their health or on the urban environment. Therefore, the issue of solid waste management is considered at the heart of achieving urban sustainability (Gowda, N., V., \& N., 2013). The municipalities should give the priority to the principle of $3 \mathrm{R}$ (waste reduction, re-use and recycle) for the effective sustainable SWM (PAN, 2008). Moreover, solid waste can be a source of locally produced biofuel rather than dumping into landfills. It reduces the buildup of greenhouse gases, saves natural resources, and acts as a renewable energy source (Modak, 2011).

\subsubsection{Case Study: ISWM Project, Nepal}

Practical Action Nepal Office (PAN) has initiated the project of Strengthening Local Capacities in Integrated Sustainable Waste Management (ISWM) in Small and Medium Municipalities of Nepal with the financial support from the European Union. The project aims to improve the health and the environmental situations of disadvantaged people living in four municipalities in Nepal (PAN, 2008). Figure (7) summarizes the most important operations of SWM learned from the experiences of the four municipalities. The main lessons learned from this case are represented in table [2]. 


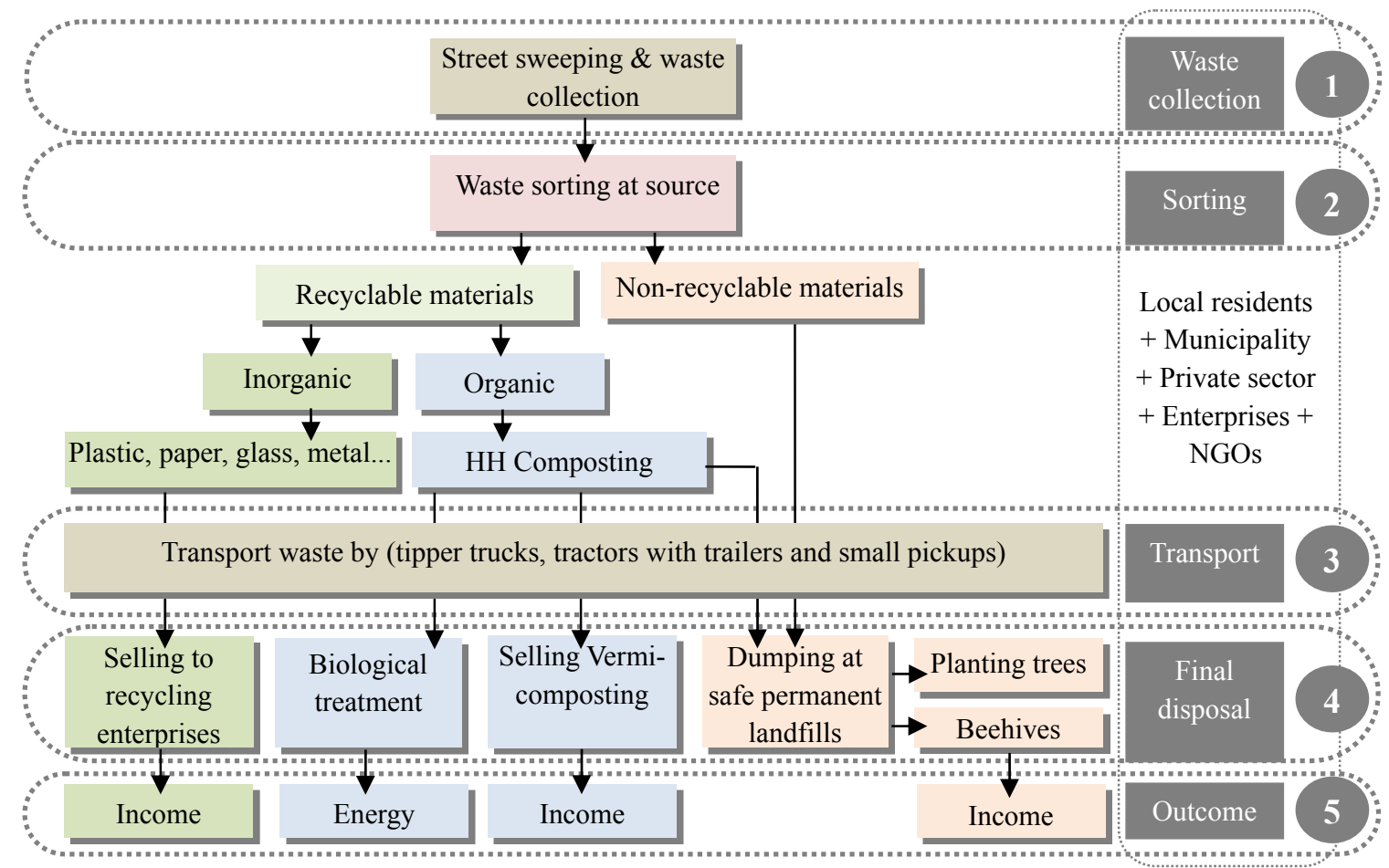

Figure 7. A diagram summarizes a range of best practices on SWM from various municipalities of Nepal.

Source: Adapted by the author from (PAN, 2008)

Table 2. The procedures and technical measures taken by PAN for SWM

\section{Procedures}

Local Participation and Empowerment

Good municipality coordination (clarifying roles and responsibilities)
Household composting

Provision of Immediate Safe Disposal Landfills
The role of local government is to coordinate the participation of the local community and raise awareness of the importance of participation, and empower local people by involving them in street sweeping and solid waste collection. Empowerment here improves communities look to the process of waste collection, and also works to draw the low-income communities' attention to that they can earn incomes through waste separation.

Municipal programs play a pivotal role in specifying the participants' responsibilities in the SWM, municipality, the locals, the private sector, local businessmen, enterprises and NGOs.

Private Sector: Due to the limited financial resources of the local government, the private sector should be attracted through political measures and the creation of the investment environment. Moreover, the private sector can create jobs for the poor in urban areas.

Local businessmen: local businessmen who deal in recycling should be invited to participate in the annual meetings of municipal councils when discussing waste management issues.

Enterprises: enterprises dealing with recycled materials can be spurred to participate in front of waiving of the local government taxes.

HH composting (household composting) entails providing every home with separate containers for recyclables before approving a construction proposal, because $\mathrm{HH}$ composting is the best option for reducing and treating organic wastes, furthermore, selling the compost is a way to increase local income.

Provision of safe and lasting landfill sites is essential for safe disposal of solid waste in order to avoid long-term health and environmental risks. 
Raising Community Awareness of SWM

Decentralization

Infrastructural Measures
Community awareness of SWM issues such as source segregation, reusing, and recycling of waste plays a leading role in developing management practice. It comes through television and radio broadcasts, exhibitions, educational tours, and Interactive programs. Holding competitions and honouring the good waste handler can spur the process. In order to improve the standards of SWM, training centers should be established.

Handling the waste as close to its source helps to reduce the burden of the accumulation of waste. It begins at home where dwellers are trained about recycling and how to sort their garbage properly.

To improve the standard of SWM, infrastructural measures should be taken for leachate collection and gas venting. Furthermore, the utilization of resources, such as covering landfill with ash, planting trees, and introducing beehives, emphasize preserving a healthy environment.

Source: Adapted by the author from (PAN, 2008)

\subsubsection{Case Study: the Floating Waste Bank project, Jakarta, Indonesia}

In the context of the SWM, it should be pointed out to the innovative mobile floating units that move on the water surface to collect waste from wet slums. Besides collecting waste, the Floating Waste Bank project teach the households the waste recycling, how to earn income through the sale of waste, together with preventing waste from being dumped into the river (see Figure 8). The units are developed by Cordaid that were emerged from a combination of Floating City Apps and the Waste Bank model. The same idea can be applied for many applications such as sanitation, health care, and education (Cordaid, 2014; UNESCO-IHE, 2015; WaterStudio, 2014).

\subsubsection{Sustainable Sanitation}

The sustainable sanitation involves more than an aspect; it should be economically applicable, socially acceptable, technically proper, and simultaneously, it should be environmentally friendly (Larsson \& Nilsson, 2003). Slum-residents often lack access to sanitation services. Unhygienic and inadequate sanitation is the second largest cause of illness in the world. It leads to contaminated waterways and food supply, as well as serious diseases such as diarrhea, raised by direct contact with human waste (WaterStudio, 2014). The problem is doubled for women in terms of embarrassment, personal security, and hygiene (UNESCO-IHE, 2015). Overcrowding and high-density neighborhoods, along with the lack of lands, infrastructure and resources make the dwellers forced to rely on unhealthy solutions such as Flying Toilets (defecating in plastic bags and then throwing it in the streets) and Pit Latrines which both result in health risks (WaterStudio, 2014). Herein, the selected experience comes from Nairobi, Kenya.

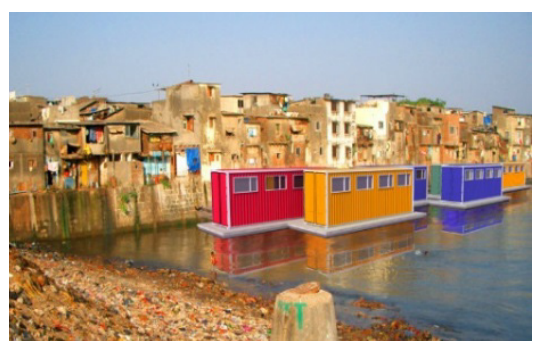

Figure 8. The Floating City Apps units designed to collect solid waste from wet slums (Meinhold, 2012)

\subsubsection{Case Study: Sanergy Project, Nairobi, Kenya}

Two students at the MIT Sloan School of Management have developed an integrated waste management model as co-founders of the social enterprise of Sanergy in Nairobi, Kenya. Sanergy aims to improve sanitation conditions and creating jobs and profit for Kenyan slum-dwellers simultaneously. The model suggests creating a sustainable sanitation cycle that has positive health, social, environmental, and economic impacts (Bettex, 2010). The model includes four stages; 1) establishing a low-cost sanitation centers networks throughout slums, 2) distributing them through franchising to local entrepreneurs, 3) collecting the produced waste using a low-cost infrastructure, and 4) converting it into electricity and fertilizer, and then selling electricity to national grid and 
fertilizer to commercial farms. Sanergy generated 771 Jobs including Sanergy team and Fresh Life Operators, produced Profit return from the sale of energy and fertilizer producers, achieved local participation and economic empowerment, and reduced the reliance on synthetic fertilizers and non-renewable energy sources (Sanergy, 2013). Table [3] summarizes the systems-based approach to solve the sanitation crisis by SANERGY.

Table 3. The systems-based approach to solve the sanitation crisis sustainably by SANERGY

The system Illustration
1.Build
made of high-quality materials that are easy to be maintained. FLTs
have a small footprint that enables installing close to homes. They are
cost-effective and hygienic as they include hand-washing facilities.

Source: Adapted from (Bettex, 2010; Sanergy, 2013)

\subsubsection{Sustainable Building Materials and Low-cost Housing}

Sustainable building materials are the materials that are locally produced and sourced (which reduce transportation costs and $\mathrm{CO}_{2}$ emissions) including recycled and waste materials. Sustainable building materials cover the three pillars of sustainability, social, environmental, and economic. Ecologically, sustainable materials have low environmental impact and they require less energy in the manufacturing, so competing modern traditional materials. The economic aspect comprises of the lower costs of materials, job and skills creation to community members, and the optimization of life-cycle performance. Socially, they encourage locals to participate and contribute to improving their health (EPA, 2011; SDN, 2009). Methods of sustainable building materials include sandbag and earth-ship construction, glass and plastic bottles, aluminum wastes, bamboo, scraps, paper, and shipping containers.

By combining local building materials and the low-income level of slum dwellers, we find that it is worth referring to low-cost housing. Low-cost housing according to the Economic Times, A. K. Lal, and The National Affordable Housing Summit Group in Australia, is the affordable housing that caters to the minimum requirements of the dwellers whose income is below the median of household income, without sacrificing the housing construction quality and, in the same time, doesn't come at the expense of the other basic needs on a sustainable basis (Lal, 1995; C. Reviews, 2016; TheEconomicTimes, 2015). To maximize the benefits of low-cost housing for the poor, it should be consider the use of efficient planning and project management, economical construction technologies and the use of the available alternate construction methods. The interest behind the use of such methods backs on the accessibility of such housing type to all (Mishra, 2014).

In this vein, prefabricated shelters serves as a platform to solve the problems of the urban slums for their advantages of cost savings for mass production, rapid assembly, and reassembly in different locations. Besides, the prefabs could be helpful as post-disaster alternatives (Taher \& Ibrahim, 2014). Also, prefabs could be useful in slum development projects as a solution in case of relocation strategies. Their modular design allows future 
expanding, and easy transportation, which makes it suitable for different needs. The large need of the poor and refugees, and their ability to self-organizing, in tandem with their labour capacity, enable them to take advantage of the prefab shelters (Meinhold, 2011; ShelterStructures, 2013). Table (4) monitors different sustainable materials and techniques, and their sustainable opportunities in construction, namewly; bamboo, straw-bale, and rammed earth-based materials such as earth-ship and sandbag. Figure [9] enriches imagination with a selective collection of innovative designs for prefab shelters. Figure [9-a] illustrates a collapsible woven fabric mobile shelter that provides water and renewable electricity (Laylin, 2014). Figure [9-b] shows a three-story prefab and modular pod house built from recycled materials (Meinhold, 2009). Figure [9-c] introduces a self-sufficient Single Pole House with, virtually, a zero footprint (Janzen, 2013). Figure [9-d] shows the M-Velope , the wooden house that can be transformed and rearranged to fit various positions (Meinhold, 2008). Figure [9-e], illustrates a low-cost flood resistant shelter built with bamboo, leaves and recycled oil containers (Designboom, 2013). Figure [9-f] shows the floating greenhouse, known as the Jellyfish Barge. It is constructed from bamboo \& recycled plastic. It produces food hydroponically; hence, it produces income \& creates jobs, with a minimal carbon footprint (Wang, 2014). Figure [9-g] shows the Vegetable Nursery made from bamboo and recycled bottles (Brooks, 2014). Figure [9-h] illustrates the Butterfly Houses made from bamboo. The butterfly-shaped roof creates natural ventilation and collects rain (Saieh, 2009).
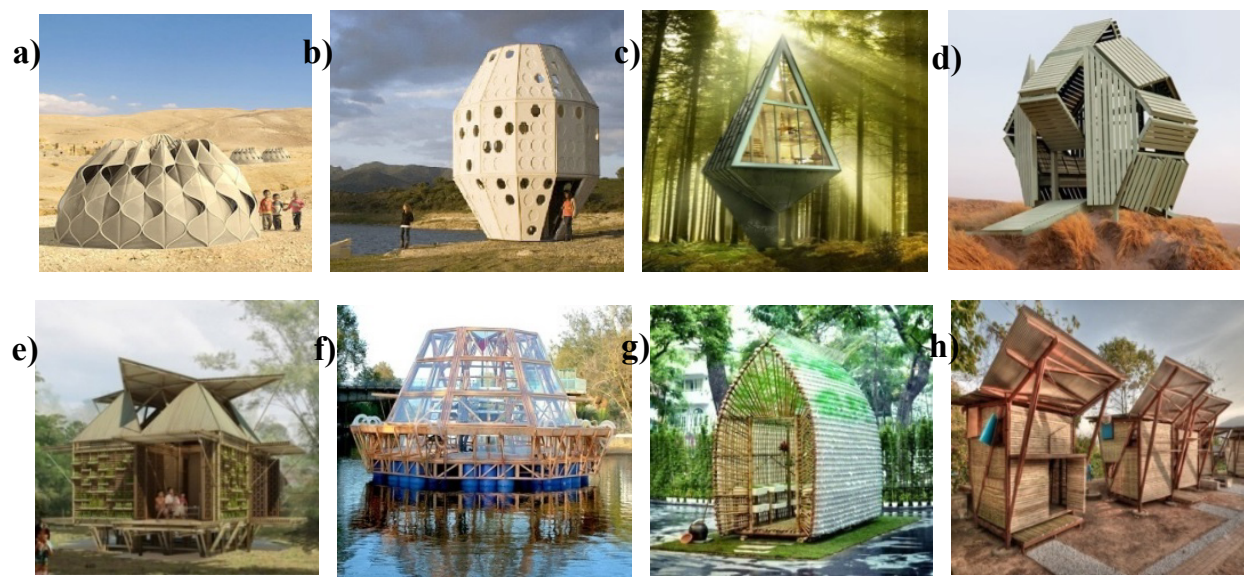

Figure 9. A review of various eco-shelters designs that could fit slums (Brooks, 2014; Designboom, 2013; Janzen, 2013; Laylin, 2014; Meinhold, 2008, 2009; Saieh, 2009; Wang, 2014) 
Table 4. The advantages of the eco-friendly low-cost materials and their technical aspects across the three dimensions of sustainability

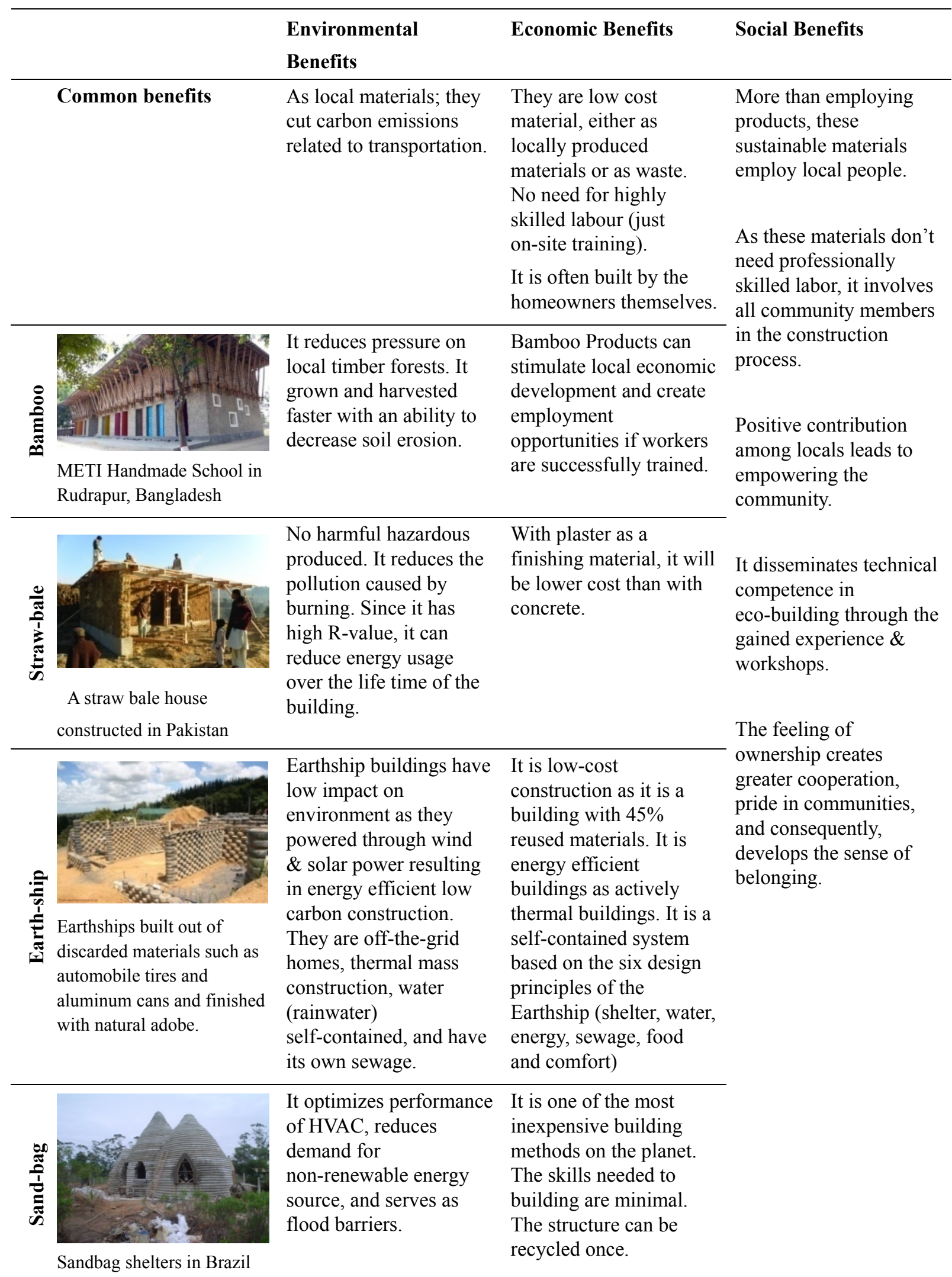

Source: adapted from; (AKDN, 2004; Barnes, Kang, \& Cao, 2006; DaycreekJournal; EarthshipBiotecture; EarthshipBiotecture; Hunter \& Kiffmeyer, 2004; Lim, 2007; Meroni, 2007; UNHABITAT, 2012a, 2012b, 2012c) 


\section{Conclusion}

The endeavours were undertaken by governments to eradicate slums and establishing a new housing, predominantly, reflect not only the ignorance of the original needs of the poor, but rather refer to the tendency to attracting investment. That is along with the failure met with many upgrading interventions because of either the shortage of lands or the difficulty of infrastructure supplies. As well as many slums development measures didn't pay attention to the resources offered by slums, as well as the omission of the long-term sustainability. So, investing those positive promising potentials, in tandem with developing a sustainable strategy to the upgrading processes show a great prospect of achieving sustainable slums. That is what this paper is seeking to.

Grounded on reviewing the selected case studies, it is concluded that slums are full of positive aspects, either represented in the vital spirits and the self- management potentials of its dwellers or rather within its value as a proper accommodation and affordable livelihood place, at least from their points of view or according to their limited income levels. It could be said that slums are urban, spatial, economic, and human wealth, which can be utilized to achieve a sustainable environment for the poor. This paper infers that poor communities themselves play a pivotal role in improving their living conditions, where they rely massively on self-efforts to bring about change. Their human capital strength is represented in; a) the slum dwellers' ability to coexist along with the various kinds of problems, b) their capabilities to self-constructed houses, c) the social and economic convergence between classes, d) the dwellers ability to communicate, and e) the participation of informal economy as the wellspring of abundant labour force. These all capabilities together qualify slum communities to make major positive differences, and as a consequence, tread several steps towards sustainability.

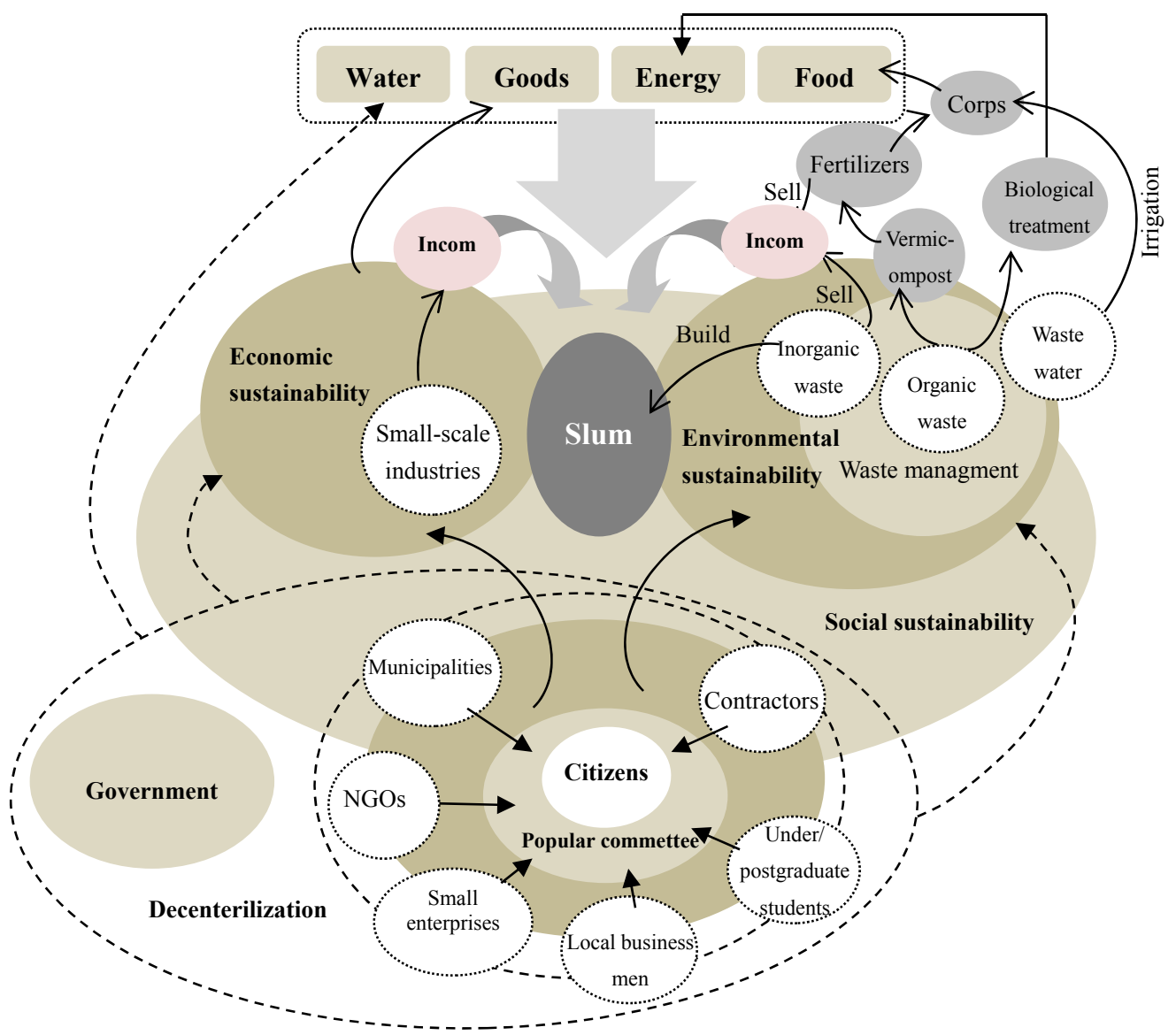

Figure 10. The conceptual framework towards sustainable slums grounding on the paper methodology

The case studies strongly suggest the great human potential of slum dwellers in solving their economic and social problems depending on self-management, while they don't have any means with regard to the environmental and health problems. So the key role of the state is the provision of the political and administrative will by joining efforts, coordinating roles, and drawing a master map based on decentralization in terms of empowering individuals (including least-represented), NGOs and enterprises within an official 
framework to ensure fulfilling the slums' sustainability goals. The decentralization policy is the cornerstone of achieving sustainable developments. It is significant to change the state's policy to enable more individual control on the path of development and reduce the large control of institutions and governors. In addition, empowering local and civil community is a crucial process in sustainable development. Civil society organizations exist in most communities and operate successfully in community development, but the problem is to enable these organizations through activation of the decentralization in the decision-making process.

Furthermore, the review proves that slum's sustainable upgrading should be a well-coordinated effort of integrating multi-sector interventions, which would eventually lead to sustainability in the light of social, economic and environmental improvements. Moreover, the review shows the individuality view of upgrading processes. In other words, participants (including NGOs, governments, community groups, private sectors, enterprises, international agencies, etc.) have addressed one issue or two at most, of sustainability in each case. The intention of this paper is to call these efforts to converge to cover the four major sustainability issues; food, energy, water, and waste through establishing a versatile case for bringing together the major aspects of sustainability. Figure (10) illustrates the concluded conceptual framework towards sustainable slums. Herein, it is worth mentioning to defining the sustainable slums as the settlements that clean the environment, generate energy, and produce food and goods.

\section{References}

Abdelhalim, K. (2010). Participatory Upgrading Of Informal Areas: A Decision-Makers' Guide For Action Retrieved from https://www.citiesalliance.org/sites/citiesalliance.org/files/CA_Images/2010_PDP_Participatory\%20Upgrad ing\%20of\%20Informal\%20Areas_Decision-makers\%20Guide\%20for\%20Action.p.pdf

AfricanSlumJournal. (2015). Murals in Korogocho Slum. Retrieved from http://www.africanslumjournal.com/murals-in-korogocho-slums/

Agrawal, V. (2014). Slums: Affects on environment. Recent Research in Science and Technology, 6(1), 74-77.

AKDN. (2004). Sandbag Shelter Prototypes- Various Locations Worldwide, 2004 Review Report. The Aga Khan Award for Architecture. Retrieved from www.akdn.org/architecture/pdf/2761_Ira.pdf

Allam, K., Osman, Y., \& Mahdi, M. (1997). Urban Renewal. Anglo Egyptian Bookshop.

Alliance, C. (2014). About Slum Upgrading. Retrieved from http://www.citiesalliance.org/About-slum-upgrading\#Why_is_slum_upgrading_important

Andrade, M. H., Aulicino, P., \& Abiko, A. K. (2011). Analysis of Sustainability in the Slum Upgrading Process: the Stormwater Subsystem and the Accessibility, Mobility and Transport. Paper presented at the Proceedings to the SB11 Helsinki World Sustainable Building Conference, Finland.

ASLA. (2010). Productive End Walls. Retrieved from http://www.asla.org/2010studentawards/134.html

Baraka, H. (2012). Egypt: Learning and earning in Cairo's Garbage City, UNESCO. Retrieved from http://unesdoc.unesco.org/images/0021/002166/216677E.pdf

Barnes, B., Kang, M., \& Cao, H. (2006). Sustainable Characteristics of Earthbag Housing. Housing and Society, 33(2), 21-32. http://dx.doi.org/10.1080/08882746.2006.11430534

Bell, B., Kumar, K. B., Lundgren, M., \& Schrempp, T. (2011). The Slum Water Business Plan Program: A Sustainable Water Solution For Marginalized Slum Communities. Retrieved from http://acara.environment.umn.edu/wp-content/uploads/2011/09/ReachOutWaterSolutions.pdf

Bettex, M. (2010). In the World: Turning Waste into Profit. Retrieved from http://newsoffice.mit.edu/2010/itw-sanergy-1119

Brooks, R. (2014). Adorable Vegetable Nursery Home Made of Bamboo and 2,000 Plastic Bottles Pops up in Vietnam.

Retrieved

from http://inhabitat.com/bamboo-and-2000-plastic-bottles-make-up-vegetable-nursery-home-in-vietnam/

Bustler. (2008). Holcim Awards Honor Sustainable Construction in Latin America. Retrieved from http://www.bustler.net/index.php/article/holcim_awards_honor_sustainable_construction_in_latin_america/

Cordaid. (2014). Floating Waste Bank- Preparation Phase. Retrieved from https://www.cordaid.org/nl/projecten/floating-waste-bank-preparation-phase/111964/

Corps, M. (2006). Guide to Community Mobilization Programming. Retrieved from 
http://www.mercycorps.org/sites/default/files/CoMobProgrammingGd.pdf

Cronin, V. L. M. (2012). Slum Upgrading in India and Kenya: Investigating the Sustainability. (Doctoral Thesis), University of Cambridge. Retrieved from https://www.repository.cam.ac.uk/handle/1810/242378

DaycreekJournal. Earthship Retrieved from http://www.daycreek.com/dc/HTML/DC_earthship.htm

Designboom. (2013). Low Cost Bamboo Housing in Vietnam By H\&P Architects. Retrieved from http://www.designboom.com/architecture/low-cost-house-for-middle-vietnam/

DID. (2014). Economic Development For Shared Prosperity And Poverty Reduction: A Strategic Framework, department of international development. Retrieved from https://www.gov.uk/government/uploads/system/uploads/attachment_data/file/276859/Econ-development-st rategic-framework_.pdf

EarthshipBiotecture. Construction Materials. Retrieved from http://earthship.com/construction-materials

EarthshipBiotecture. A Look at the Models of Earthships. Retrieved from http://earthship.com/a-look-at-the-models-of-earthships

EPA. (2011). Why Build Green? Retrieved from http://archive.epa.gov/greenbuilding/web/html/whybuild.html

Fahmi, W., \& Sutton, K. (2010). Cairo's Contested Garbage: Sustainable Solid Waste Management and the Zabaleen's Right to the City. Sustainability, 2(6), 1765-1783. http://dx.doi.org/10.3390/su2061765

Fahmi, W. S., \& Sutton, K. (2006). Cairo's Zabaleen Garbage Recyclers: Multi-Nationals' Takeover and state Relocation Plans. Habitat International, 30(4), 809-837. http://dx.doi.org/10.1016/j.habitatint.2005.09.006

GarbageDreams. (2010). Garbage dreams. Retrieved from http://garbagedreams.com/

Goswami, S., \& Manna, S. (2013). Urban Poor Living in Slums: A Case Study of Raipur City in India. Global Journal of Human-Social Science Research, 13(4), 15-22.

Gowda, K., N., C. M., V., S. M., \& N., H. B. (2013). Solid Waste Management in the Slums and Squatter Settlements in the City of Bangalore. International Journal of Scientific and Research Publications, 3(2), $1-10$.

Gudran. Retrieved from http://gudran.com/

HolcimAwards. (2009). Water for all:Solar water heating rainwater tower, Florianópolis, Brazil. Retrieved from $\mathrm{http} / / /$ download.holcimfoundation.org/1/docs/A09/A09B/2ndHolcimAwards_Essay_12_Florianopolis.pdf

Howeidy, A., Shehayeb, D. K., Göll, E., Halim, K. M. A., Séjourné, M., Gado, M., ... Cobbett, W. (2009). Cairo's Informal Areas between Urban Challenges and Hidden Potentials. Retrieved from http://www.citiesalliance.org/sites/citiesalliance.org/files/CA_Docs/resources/Cairo's\%20Informal\%20Area s\%20Between\%20Urban\%20Challenges\%20and\%20Hidden\%20Potentials/CairosInformalAreas_fulltext.p $\mathrm{df}$

Hunter, K., \& Kiffmeyer, D. (2004). Earthbag Building: The Tools, Tricks and Techniques: New Society Publishers.

Janzen, M. (2013). Primeval Symbiosis -Single Pole House. Retrieved from $\mathrm{http} / / / \mathrm{www}$. tinyhousedesign.com/primeval-symbiosis-single-pole-house/

Johansson, C. (2010). Colouring up the Favelas of Rio de Janeiro. Retrieved from http://www.lostateminor.com/2010/05/19/colouring-up-the-favelas-of-rio-de-janeiro/

Johnsrud, H. (2009). Habitat Report 2009. Retrieved from http://www.niku.no/filestore/Publikasjoner/Internasjonale_publikasjoner/HabitatReport2009.pdf

Lal, A. K. (1995). Hand Book of Low Cost Housing: New Age International, New Delhi.

Lanrewaju, A. F. (2012). Urbanization, Housing Quality and Environmental Degeneration in Nigeria. Journal of Geography and Regional Planning, 5(16), 422-429. http://dx.doi.org/10.5897/JGRP12.060

Larsson, E., \& Nilsson, M. (2003). Towards Sustainable Sanitation in Slum Areas: A Field Study in Mumbai, Linköping. Retrieved from http://www.diva-portal.org/smash/get/diva2:640967/FULLTEXT01.pdf

Laylin, T. (2014). Collapsible Woven Refugee Shelters Powered by the Sun. Retrieved from $\mathrm{http}: / / \mathrm{www}$.greenprophet.com/2014/03/collapsible-woven-refugee-shelters-powered-by-the-sun/

Lim, J. C. S. (2007). Hand-Made School, 2007 On Site Review Report. Retrieved from 
http://www.akdn.org/architecture/pdf/3392_Ban.pdf

Lukeman, Y., Bako, A., Omole, F., Nwokoro, I., \& Alakinde, M. (2014). Environmental Health Condition of Slum Dwellers of Ijora-Badia Area of Lagos State, Nigeria. Academic Journal of Interdisciplinary Studies, 3(4), 79-88. http://dx.doi.org/10.5901/ajis.2014.v3n4p79

Mahgoub, Y. (2014). Slums as Fortune - Slums and Sustainability - Sustainability for the Poor. Retrieved from http://kenanaonline.com/users/YasserMahgoub/posts/621342

Meinhold, B. (2008). M-Velope Transformer House For Sale at Neiman Marcus. Retrieved from http://inhabitat.com/transformable-mvelope-by-michael-jantzen/

Meinhold, B. (2009). Shelter No 2: An Affordable Prefab Pod. Retrieved from http://inhabitat.com/shelter-no-2-an-affordable-prefab-pod/

Meinhold, B. (2011). Inhabitat Blocks House: Because Slums Need Prefab Modular Homes Too. Retrieved from $\mathrm{http}: / /$ inhabitat.com/portable-and-modular-prefabricated-slum-housing-concept/

Meinhold, B. (2012). Waterstudio.nl Proposes Floating City Apps To Aid Slums Affected By Rising Sea Levels. Retrieved from http://inhabitat.com/waterstudio-nl-proposes-floating-city-apps-to-aid-slums-affected-by-rising-sea-levels/

Meroni, A. (2007). Creative communities: People inventing sustainable ways of living.

Mishra, G. (2014). Materials for Low Cost Housing. Retrieved from $\mathrm{http}$ //theconstructor.org/building/materials-for-low-cost-housing/5352/

Modak, P. (2011). Shanghai Manual - A Guide for Sustainable Urban Development in the 21st Century. Retrieved from http://www.un.org/esa/dsd/susdevtopics/sdt_pdfs/shanghaimanual/Chapter\%205\%20-\%20Waste_managem ent.pdf

Mourad, M. (2012). Recycling In Manshiet Nasser. Retrieved from http://cairobserver.com/post/20276502104/recycling-in-manshiet-naser\#.ViAx_yuM4-N

Nazmy, N. M. (1993). Urban Upgrading of Slum Areas: Evaluation of "Zabbaleen Manshiet Nasser" Project in Cairo. (Master Thesis), Faculty of Engineering, Ain Shams University, Cairo.

Obscura, A. (n.d.). Cairo's Garbage City, Slum Settlement Filled with Mountains of Garbage. Retrieved from http://www.atlasobscura.com/places/garbage-city

Oosterlynck, S., Broeck, J. V. d., Albrechts, L., Moulaert, F., \& Verhetsel, A. (2011). Strategic Spatial Projects: Catalysts for Change. Routledge.

PAN. (2008). Best Practices on Solid Waste Management of Nepalese Cities. Retrieved from https://practicalaction.org/media/download/7018

Purcell, R. (2012). An International Perspective on: Asset Based Development: Dharavi and Slum Dwellers International. Paper presented at the FCDL Conference, Derbyshire, UK.

Reviews, \& Cram101Textbook. (2012). E-Study Guide for: Preventing and Reducing Juvenile Delinquency: Cram101.

Reviews, C. (2016). Transactions and Strategies, Economics for Management: Economics, Economics. Cram101.

Rockefeller. (2013). Decision Intelligence Document: Constrained Opportunities in Slums Economies. Retrieved from

https://www.rockefellerfoundation.org/app/uploads/Constrained-Opportunities-in-Slum-Economies.pdf

Saieh, N. (2009). Soe Ker Tie House / TYIN Tegnestue. Retrieved from http://www.archdaily.com/25748/soe-ker-tie-house-tyin-tegnestue

Sanergy. (2013). The Sanergy Model. Retrieved from http://saner.gy/our-work/the-sanergy-model

SDN. (2009). The Struggle for Integrated Sustainable Settlements. Retrieved from http://www.sustainabledevelopmentnetwork.com/manual1/INTEGRATED\%20SUSTAINABLE\%20SETTL EMENTS.pdf

ShelterStructures. (2013). Portable Shelters Offer Many Benefits and Purposes. Retrieved from http://www.shelterstructures.com/2013/07/12/portable-shelters-offer-many-benefits-and-purposes/ 
TADAMUN. (2013). Paving the Streets of Mìt 'Uqba, Creative Commons Attribution. Retrieved from http://www.tadamun.info/?post_type=initiative \&p=497\&amp;lang=en\&lang=en

Taher, M. T., \& Ibrahim, A. (2014). Transformation of Slum and Squatter Settlements: A Way of Sustainable Living in Context of 21 st Century Cities. American Journal of Civil Engineering and Architecture, 2(2), 70-76. http://dx.doi.org/10.12691/ajcea-2-2-3

TheEconomicTimes. (2015). Definition of 'Affordable Housing'. Retrieved from $\mathrm{http} / /$ economictimes.indiatimes.com/definition/affordable-housing

TRP. (2012). The World is a Ghetto: Global Slums - Out of Sight and out of Mind: Deterioration of the Human Condition. Retrieved from https://theredphoenixapl.org/2012/03/16/the-world-is-a-ghetto-global-slums-out-of-sight-and-out-of-mind-d eterioration-of-the-human-condition/

UN. (2005). Implementation of the first United Nations Decade for the Eradication of Poverty (1997-2006), The centrality of employment to poverty eradication: Report of the Secretary-General. Retrieved from http://www.un.org/esa/socdev/poverty/documents/SG_poverty\%202005.pdf

UNESCO-IHE. (2015). Innovations for Water and Development: Floating solutions for upgrading Wet-Slums. Retrieved from http://www.unesco-ihe.org/sites/default/files/unesco-ihe_innovations_e.pdf

UNESCO. (2014). Water for the Millennium Development Goals, World Water Assessment Programme. Retrieved

from http://www.unesco.org/new/fileadmin/MULTIMEDIA/HQ/SC/pdf/WWAP_Water_and_MDGs.pdf

UNFPA. (2007). State of World Population 2007. Retrieved from http://www.unfpa.org/sites/default/files/pub-pdf/695_filename_sowp2007_eng.pdf

UNHABITAT. (2012a). Going Green: A Handbook of Sustainable Housing Practices in Developing Countries. United Nations Human Settlements Programme (UN-HABITAT), Nairobi.

UNHabitat. (2012b). Green Materials: Bamboo. Green Materials technical notes series. Retrieved from http://unhabitat.org/green-building-materials-fact-sheet-bamboo/

UNHabitat. (2012c). Green Materials: Straw-Bale. Retrieved from http://www.gnshousing.org/index.php/search-results/item/download/131_b416ef899f9f0f4f28df46b35d1bf3 $7 \mathrm{e}$

UNHabitat. (2012d). Sustainable Housing For Sustainable Cities, A Policy Framework For Developing Countries, United Nations Human Settlements Programme 2012. Retrieved from Nairobi: http://peoplebuildingbettercities.org/wp-content/uploads/2013/06/Sustainable-Housing-Policy-Framwork.pd $\mathrm{f}$

UNHABITAT. (2014). Background $\quad$ Paper. $\quad$ Retrieved http://unhabitat.org/wp-content/uploads/2014/07/WHD-2014-Background-Paper.pdf

Wang, L. (2014). Solar-Powered Floating Greenhouse is an Off-Grid Solution to Food Scarcity. Retrieved from http://inhabitat.com/solar-powered-floating-greenhouse-is-an-off-grid-solution-to-food-scarcity/

WaterStudio. (2014). Floating City Apps. Retrieved from https://www.floatingcityapps.com/blog/?page_id=55

WorldBank, \& UNCHS(Habitat). (2001). Cities Alliance for Cities without Slums. Retrieved from http://web.mit.edu/urbanupgrading/sponsor/ActionPlan.pdf

\section{Copyrights}

Copyright for this article is retained by the author(s), with first publication rights granted to the journal.

This is an open-access article distributed under the terms and conditions of the Creative Commons Attribution license (http://creativecommons.org/licenses/by/4.0/). 